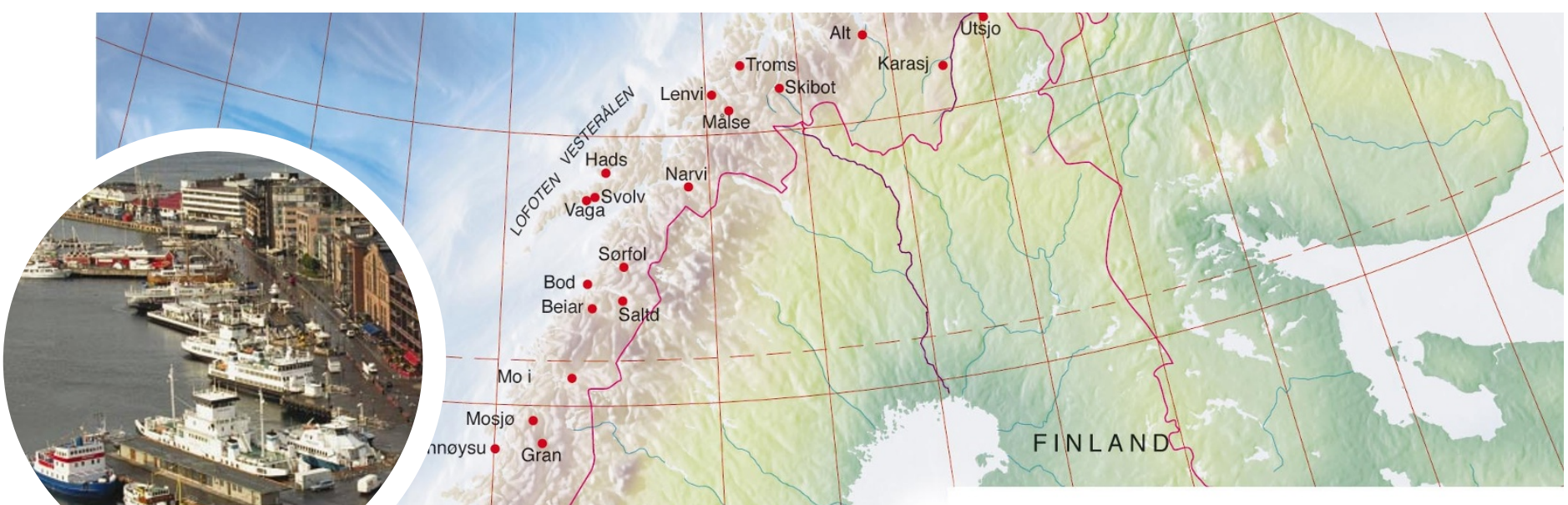

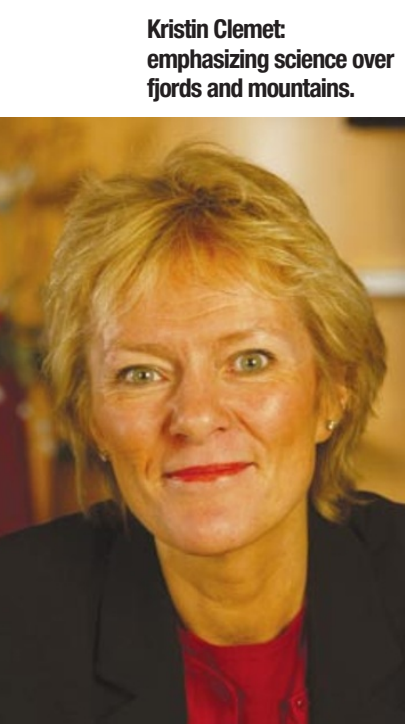

Kristin Clemet: emphasizing science over fjords and mountains.
SWEDEN

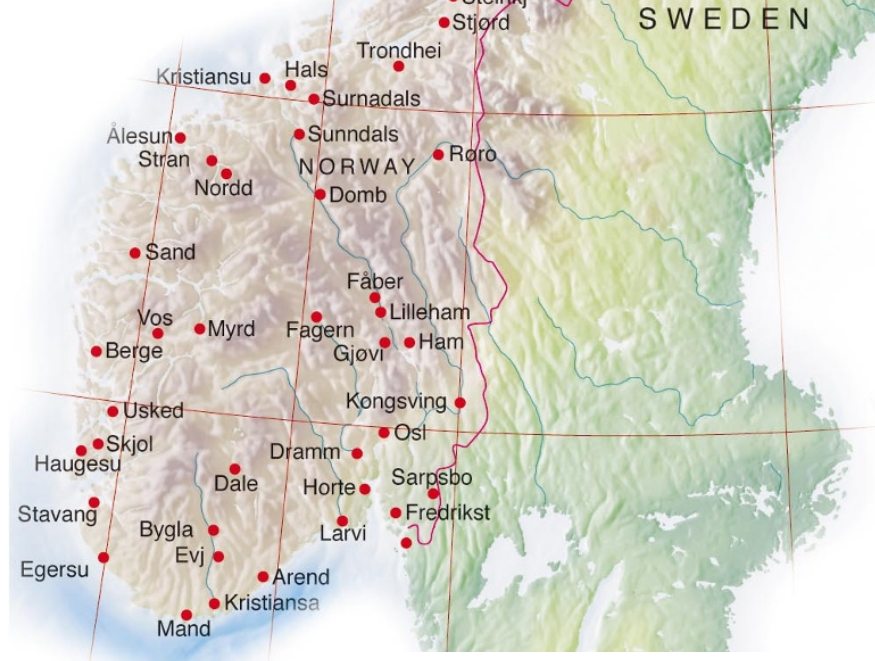

N

orwegian research institutions have historically tried to temper potential international recruits' perceptions about the country's cold, dark winters with talk of its natural beauty and excellent skiing. That approach has not been entirely successful. There are usually more Norwegian scientists leaving than foreign ones arriving. But the new government elected last autumn is planning a different tack.

"I think it's wrong to try to attract researchers with the fjords and the mountains," says education and research minister Kristin Clemet. "We need to attract them with good research opportunities and afterwards we can tell them about all the other things."

To create those opportunities, the country is investing the missing ingredient - money. Norway lags far behind its Nordic neighbours Sweden which spends three times as much per capita on biomedical research — and Denmark, which spends twice as much. At $1.7 \%$ of gross domestic product (GDP), Norway's investment in research and development is well below the average of $2.2 \%$ given by the Organisation for Economic Co-operation and Development (OECD).

Norway plans to close that gap by tapping into something it has plenty of, at least in the short term oil. Oil revenues were used to set up the Research Investment Fund in 1999, as a source of extra funding for science. Clemet hopes that the fund, plus incentives for university researchers to commercialize their work

\section{Turning oil into science} Norway

and tax credits to promote industrial investment, will bring Norway's biomedical funding in line with its neighbours, and boost overall R\&D up to or above the OECD average.

The fund, at 13 billion kroner (US\$1.7 billion), is ahead of schedule to make its 15-billion kroner target for 2005. The current year is pivotal for science in Norway, as it marks the first time the yield, estimated at 525 million kroner for 2002, will be invested in two large-scale projects: 100 million kroner will be sunk into a functional-genomics initiative and another 100 million will establish 10 centres of excellence.

\section{CENTRE FIELD}

Clemet hopes that the two projects will raise the country's international profile and attract foreign researchers - important because the country produces fewer PhDs than other Nordic countries. So, if it wants to grow, it will have to follow Ireland's lead (see Naturejobs 4-5; 21 March 2001) and lure Norwegian researchers back as well as tempting scientists from other countries.

The centres, covering four areas of science, face different challenges. Marine research and science that examines the intersection between energy and environment are "obvious" for Norway, says Clemet. The marine biotech business is Norway's secondbiggest industry and the country already has a role in sequencing the salmon genome, so it should not be 
hard to attract industry interaction and interest from abroad. Environmental science is also targeted for research, as the country already has infrastructure such as the Norwegian Polar Institute.

The other two areas, medicine and health, and information technology, will require more work to build up. Still, they have established a base, says Harald Stenmark, a cell biologist at Radium Hospital in Oslo.

$\mathrm{He}$, like all the scientists in the 40 groups competing to become centres of excellence, is waiting to see if he will make the grade. Centre-of-excellence status, with its average 10 million kroner of funding for up to 10 years, would allow Stenmark to double the number of funded PhD students and postdocs in his lab.

It could also mean that David Gillooly, a postdoc in Stenmark's lab, could stay in the country, which would suit both him and Clemet - Gillooly because he is married to a Norwegian, and Clemet because she has explicitly stated that the centres must attract and retain foreign scientists.

\section{FUGE STATE}

In some respects, FUGE, the functional genomics project, which is a bit further along than the centres, is serving as a test case for how well Norway can scale up its science. Clemet likes it because it combines marine, biotech and environmental science. And to succeed, the programme will require both contact with international partners - such as Canada, which is working with Norway to sequence the salmon genome - and industry, which is looking at the science behind many aspects of salmon raising.

"We want to be the leader in the world of salmon genomics," says Lars Aukrust, a member of the Research Council of Norway. But he thinks that will require more leadership from the government; he and the scientists who proposed FUGE had hoped the project would be funded at three times the rate. "There is no sense of urgency," Aukrust says of the government.

But Ole Marvik, chairman of the Norwegian Bioindustry Association, says the country does not yet have enough infrastructure to absorb a bigger boost.

"You cannot create 500 trained people overnight even if you had the money," he says.

He notes that the Norwegian biotech industry, with what he calls 45 "true" companies - about half of which are less than three years old — could not sustain excessively rapid growth. Marvik, who is also founder and chief executive of Affitech, an Oslo-based biotech company, has already competed in one bidding war with another biotech company over a recruit and would rather not get into similar battles with universities.

Despite the modest starting size of FUGE and the centres, the two programmes will clearly have an impact on recruitment and employment, says Marvik, with a few hundred positions created immediately, and more commercial spin-offs and academic-industrial collaborations to follow. Although the money is not massive compared with the sums bandied about in the United States, it is enough to encourage more cooperation within Norway and to foster international collaborations. "The amount of money spent is not an important thing alone," Marvik says. "What's important is how this investment is creating a momentum."

Although Werner Christie, chairman of Norway's Biotechnology Advisory Board, agrees with Aukrust

\section{Low pay, great scenery}

In some ways, Fahri

Saatcioglu, a researcher at the University of Oslo's biotech centre, is an example of the kind of person Norway wants more of - he is foreignborn, with ties to universities on both coasts of the United States. But the Turkish scientist's tenure in Norway also points to the difficulties of attracting more expatriates to the country.

For instance, he says, postdoc stipends are "quite low in Norway, even in comparison to other Nordic countries".
This makes it difficult to fill posts. Also, there is not a substantial difference between a postdoc's salary and that of a junior professor which could deter foreign nationals who are accustomed to a higher pay grade.

“That's something that really needs to be fixed," he says. Still, for Saatcioglu, the benefits outweigh the disadvantages. He has learned to ski and enjoys the country's spectacular scenery. "I moved here with a sense of adventure," he says. P.S. that the rate of investment should be increased, he thinks that the first round of both programmes have given the country enough momentum. "I think we will catch up," says the former health minister.

But that will require more than just a sustained investment, says Christie, who spent 1999-2001 in San Francisco learning the mechanisms of the bay area's biotech base. There he witnessed "the power of beer and pizza", the fuel that drives networking in the United States. "We have to learn that in Norway," he says.

That educational process has already begun, says Ole Petter Ottersen, science dean of the University of Oslo. Oslo has joined Gothenburg, Sweden, in a collaborative project called Medcoast Scandinavia to form a 'bioregion' in the hope of attracting more venture capital - something which the area is short of. He hopes that the nascent bioregion will eventually join forces with the more established Medicon Valley that straddles Copenhagen in Denmark and Lund in Sweden (see Naturejobs 10-12; 21 June 2001).

Establishing FUGE and the centres of excellence will play a key role in forming Norway's part of that broader bioregion. Clemet hopes to speed up both projects if they go well in the first year,

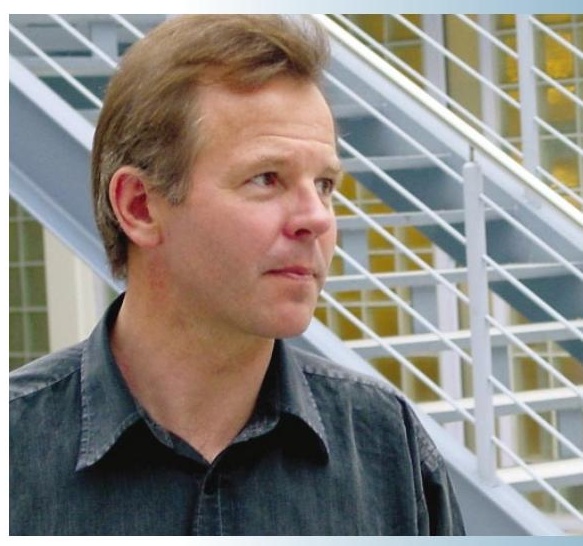

Ole Petter Ottersen hopes to establish a new bioregion in Norway. perhaps by increasing funding for FUGE and by introducing more centres of excellence. "If we can give researchers good working conditions and interesting challenges, they'll come even if it's cold in Norway," she says.

Paul Smaglik is editor of Naturejolss.

Web links

Norwegian Polar Institute 》 www.npolar.no

FUGE 》www.forskningsradet.no/fag/andre/fuge

Research Council of Norway www.forskningsradet.no/english

Bloindustry Association 》www.biotekforum.no/nba/nba.shtml 